\title{
A Walk on the Wild Side: A Critical Geography of Domestication
}

\author{
Kay Anderson \\ 1997. Progress in Human Geography 21(4), 463-85. ${ }^{1}$
}

\section{Introduction}

Few interventions in the world's diverse environments have been as influential as those taken some 11,000 years ago when Neolithic peoples began to domesticate select species of plants and animals. Two to three million years of food collection on the part of human societies gave way to new forms of settlement and livelihood associated with the production of particular food sources. Through an infinite number of modifications, not necessarily or uniformly adopted by all societies, humans began to transform nature into new forms of life and product.

By today, such interventions on the part of western societies have become highly orchestrated, but no less experimental, projects of selective breeding for human purposes. The next generation of farmyard animals - dubbed "super sheep" and "cloned cattle" - will be mass-produced creatures that can grow faster, produce more milk and meat, and resist more disease (The Daily Telegraph, 22 May 1996). The harnessing of science and biotechnology to the domestication of plants and animals has enlarged the ground of human control over nature. During the intervening millennia between Neolithic times and the present, with enormous regional variation, trees were cleared, crops were planted and commercialized, animals were raised as livestock, soils were fertilized and habitats for human settlement were made. Publications.

1 This chapter was reprinted with permission to re-use from Kay Anderson and SAGE 
So breath-taking is the scope of this transformation that the domestication of nature appears to be a universal process of humankind, the unfolding of laws of evolution which made humans lords of creation and animals our organic hosts. The significance of the process is reflected in a huge volume of academic literature, particularly in the fields of geography, archaeology, anthropology and zoology where plant and animal domestication has been examined for the light it throws on environmental histories, evolutionary process, species change under selection, population growth and patterns of human livelihood and settlement (e.g., CluttonBrock, 1981, 1989; Harris, 1996; Hemmer, 1990; Sauer, 1952; Smith, 1995; Ucko and Dimbleby, 1969; Zeuner, 1963;). Yet to date, and despite the enormous environmental, commercial and social impacts of the process, domestication has escaped critical, sociological attention from human scientists (although see Noske, 1989, Chap. 2; Tuan, 1984; and critiques of contemporary biotechnology, especially Haraway, 1991). It is a silence that is not only surprising but also one that continues to constrain the imagining of alternative ethical and practical relationships between humans, animals and environments.

This article takes a more critical look at the process of animal domestication [...] I take domestication to mean a process of drawing animals into a nexus of human concern where humans and animals become mutually accustomed to conditions and terms laid out by humans; where that which is culturally defined as nature's "wildness" is brought in and nurtured in some guises, exploited in other guises, mythologized and aestheticized in still other forms of this complex cultural practice. Conceived in this way, domestication has broad practical and theoretical significance. I wish to argue in what follows that domestication frames relations that extend beyond animals to include other human groups encountered as people inhabit and move about the world (Anderson, 1998). Domestication practices have had a political content, I shall argue, that not only defined the relationship of humans with certain animals but also intrahuman relationships between groups defined on the basis of race and gender.

This article is structured in two major parts as follows. In the first part, I review existing treatments of the concept of domestication in geography, from the late nineteenth century and beyond to the Berkeley school of cultural geography. Those schools of thought conceived of domestication within a culture-ecology framework which, I argue, inhibited the critical attention to the process that it deserves. In the second part of the article, I therefore begin the task of critically deconstructing the process of domestication. I seek to connect practices of domestication to recent critical geographies of power, discourse, nature and identity. 


\section{What is Plant and Animal Domestication?}

The history of plant and animal domestication is gradually being reconstructed from evidence obtained from archaeological sites. There is agreement, however, that during Neolithic times and probably earlier, humans in various parts of the world began to confine and breed artificially select life-forms for certain physical and behavioral characteristics. Plants and animals deemed suitable for service and company were incorporated into the social structure of human communities where they became objects of ownership, purchase and exchange.

Domestication was not the prerogative of any one society. Nor was it a onetime event. Despite some controversial evidence that dogs, sheep and goats may have been responding to domestication pressures some 1,000 years before plants (e.g., Henry, 1989), it is widely accepted that plants were domesticated before animals. Tuberous species rich in carbohydrates such as sago palms, taro and yam were selected between approximately 11,000 and 9,000 BC; later, cereals were adopted, and as recently as the twentieth century, mint and ginseng became objects of agricultural production (Busch, 1991). As for animals, the first creatures to be incorporated into regions of simple plant domestication (in south Asia) were dogs, goats, pigs and sheep (Sauer, 1952). Such animals were bred, possibly initially in protective relationships as pets (Serpell, 1989), and from them, the domestic strains developed. Living artifacts hybrids of "culture" and "nature" - were brought into socially embodied form.

Over generations, and a period of about 5000 years in the case of the major animal domesticates, the evolution of creatures was reorganized so that their natural state became one of coexistence with humans. As the docility of animals increased, their practical utility to humans was enhanced. Humans could have security of survival within a greater range of habitats, settled abodes and more sedentary lives. Humans themselves became domesticated (Wilson, 1988), though increasingly, archaeologists argue that human settlement occurred in tandem with breeding experiments (for European sites, see, e.g., Hodder, 1990). Regardless, human populations began to multiply in conjunction with food storage, agriculture and animal husbandry, and the conditions were created for the more complex urban life of the Bronze Age. Fellow life-forms were drawn into the fold of human activity - or "domus" - progressively "improved" in human terms, and stripped of what came to be called their "wildness".

\section{The "Animal" Turn as Biological Determinism?}

One of the most persistent themes within western thought has been the concern with what makes us human, an impulse that has seen numerous efforts to specify how we are different from animals (and also machines). It is not my intention to chart the complexity of the efforts of diverse world cultures to conceptualize humanity in 
relation to animals. Rather I seek to draw out the political significance, in cultures with a European tradition, ${ }^{2}$ of the turn to animal domestication and the resonances of that process through wider social relations. My objective is to use the lens of critical cultural geography to situate such relations within a broader nature-society problematic, one that is typically used in geography to theorize within political economy frames and strands of historical materialism (see, e.g., Smith, 1984; Fitzsimmons, 1989).

Challenges to the conceptual boundaries segregating "humanity" and "animality" are my point of departure for examining the process of animal domestication. The human-animal divide is increasingly being problematized in the human sciences, along with other conceptual distinctions of mind-body/male-female that over time interacted with it. Such dualistic thought is under challenge by postcolonial and feminist scholars such as Birke (1995) and Plumwood (1993), who in her book Feminism and the Mastery of Nature unsettled the fixity of not only the category "animal" but also, more radically, "human" (see later discussion). The study of animals has thus been brought into a culture/society framework from which it has long been excluded (see, e.g., Sheehan and Sosna, 1991; Arluke and Sanders, 1996; and contributions to the new journal Society and Animals). The sociological turn to animals has also recently registered in geography where "animal geography" is being integrated into human geography (Philo, 1995; Wolch and Emel, 1997) and urban geography, for example, is being retheorized as a field of "trans-species relations" (Wolch et al., 1995).

There is commonly resistance among human scientists to drawing analogies between relationships in "nature", on the one hand, and social relations, on the other the latter being deemed to be resolutely "outside" nature. There are fears of lapsing into the determinism and reductionism of sociobiology (e.g., Wilson, 1979) where explanatory recourse for social life is made to inanimate forces such as evolution, fitness and species survival. Such forces are (quite rightly) seen to deny agency and power to humans.

Humans are not in the grip of their instincts and senses, it is often asserted, whereas animals are. Animals are little more than their biology, this is what constitutes their animalness; they are mere puppets of genes. This uncomplicated conceptualization of animality is now long since out of date with literatures on the cultural and linguistic life of animals. The findings of that scholarship do not form the subject matter of this article, however. Nor does my interest in domestication stem from a position of "animal rights", though the escalation of critiques of animal agriculture on the grounds that animals have intrinsic value and recognizable suffering, certainly gives currency to the topic (Regan, 1983; Singer, 1975). Rather, I will

${ }^{2}$ A discussion of other cultural traditions' relations with domesticated animals would be an equally valid subject for analysis. 
become interested in the article in how notions of animality came to inform concepts of "human" identity in European-derived societies; how the concept of animality holds up a window to ideas of "human" nature. My way forward, then, is to historicize the dualisms of human/animal and culture/nature (see also Haraway, 1991; Ingold, 1995; Latour, 1993) within what I shall be calling a politics of domestication. First, however, the article undertakes an assessment of perspectives on domestication in human geography.

\section{Evolutionary Perspectives on Domestication in Geography}

Animal and plant domestication has long been considered central to the concerns of human geography. This is not surprising given that domestication made possible the development of pastoral and agricultural economies with enormous implications for landscape form, and the relations of people to environment and each other. In what follows, my intention is to highlight the culture-ecology frame within which domestication has to date been conceived in geography. This provides my point of departure from other schools of thought in cultural geography for whom, as we shall see, domestication was an unproblematized phenomenon - a natural extension of man' ${ }^{3}$ rise to ecological dominance of the earth. I do not perceive this as a call to inflame the debate about entire schools of cultural geography, however (see, e.g., Cosgrove et al., 1993; Price and Lewis, 1993), but rather as an opportunity to engage with diverse perspectives on the phenomenon of domestication.

In 1955, an international symposium under the chair of Carl Sauer of the University of California, Berkeley, was convened to review the impact on the earth's surface of "man's evolutionary dominance" (Thomas, 1956). Drawing on late nineteenth-century scholars such as George Perkins Marsh who wrote the influential Man and Nature (1864), the French geographer Paul Vidal de la Blache, and the Scottish geographer Marion Newbigin's Man and his Conquest of Nature (1912), the symposium sought to "address the impact of domestication and civilization on animals and human beings" (Thomas, 1956, xxxv). One scholar whose work was considered particularly relevant was the geologist, Nathaniel Shaler, who had written specifically on the topic of animal domestication in the 1890s.

In a broader analysis of "man's estate on earth", Shaler (1896) identified domestication of the "forms of wilderness" as the point that marked man's transition

${ }^{3}$ In this article, I retain the practice of speaking in the male voice because the falsely universalist premise implicit in the usage of the time - of man as culture, reason, progress - was logically crucial to the narratives that were constructed. The decision to retain this style is only possible in the context of persuasive feminist and anti-racist challenges to the universalistic truth-claims (e.g., Rose, 1993). Where the term 'man' appears to have been inflected with especially transcendent qualities, I capitalize the word and its corollaries Culture, Reason, and Progress. 
beyond "the threshold of barbarism". It was an advance of culture, he claimed, that separated people from creatures of the wilderness. After all, the process of domestication did not lie only with functional need on the part of humans, but with "aesthetic values" and inclinations to bring "other beings into association with our own lives". Such "sympathetic" tendencies were acquired as the "ancient savage impulses" of the "care-taking soil tiller" were "slowly worn away" in the task of husbanding animals. To the work of domestication, then, "perhaps more than to any other cause, we must attribute the civilisable and the civilised state of mind" (Shaler, 1896, 222). In short, such habits of mind and conduct distinguished Man both temporally and conceptually as Culture, from beast conceived of as instinct.

Domestication was for Shaler, then, the force through which culture understood normatively as a civilizing attribute - had arisen and evolved, a view that enabled him to cast within an evolutionary frame the relations of man and animal. And yet, such "humanizing influences due to the care of animals" were not universally shared by people, he observed. The distinction between wild and tame was meaningless, Shaler claimed, to "the savage". So just as creatures acquired a "tone of civilization" when they "abandon $\{$ ed $\}$ those ancient habits of fear and rage which were essential to their life in the wilderness" (Shaler, 1896, 226), savage men could only be brought into a "higher state of perfection" - if not literally through selection - then under the conditions of civilization (a claim which will become relevant later in the article).

As long as domestication was conceived as the civilizing activity that marked (at least some) humans' separation from animals, its understanding could feed into ethnocentric ideas that were in circulation during Shaler's era (see Livingstone, 1984). More precisely, the activity of domestication seems to have been taken as a fundamental criterion for ranking groups of people called "races". The work of domestication has "in the main", Shaler $(1896,220)$ claimed, "been effected by our own Aryan race". In the continent of Africa, excepting the "lands about the Mediterranean and the Red Sea, the native peoples have never attained the stage of culture in which men become inclined to subjugate wild animals" (Shaler, 1896, 247). Hence such men had themselves remained savage.

The terms of reference of the 1955 symposium echoed many of Shaler's views. The meeting grew out of a concern about the environmental impacts that were said to have transpired since "man supplemented organic evolution with a new method of change - the development of culture" (Thomas, 1956, viii). This was taken to mean "man's growing knowledge of, and control over, forces external to himself" (viii) as testified by the technology of domestication. Such control had attended man's rise to the status of (what was called) "ecologic dominant".

Carl Sauer, the convenor of the symposium's retrospective focus, had already written about the origins and dispersal of agriculture. For Sauer (1952/1969), the evolution of culture in man had given rise to "innovations" which - in an intellectual context of economic and environmental determinism - he argued deserved their own 
analysis. In Sauer's $(1956,2)$ words: "Man alone ate of the fruit of the Tree of Knowledge and thereby began to acquire and transmit learning, or culture." Unlike Shaler, however, Sauer saw no variability in the capacities of different races to modify landscapes through domestication, and would tolerate no claims about the special ability of Aryans to domesticate. Sauer's theoretical objective, after all, was to make a case for the instrumental role of culture as a "universal capacity" of "even the most primitive people", including "the obtuse Tasmanians" (Sauer, 1956/1969, 11).

Sauer's (1952) inquires into the origins of agriculture led him to hypothesize, following the German geographer Eduard Hahn, that domestication had (what he called) "cultural" rather than "economic" origins. At least some animals became domesticated, he argued, to serve in the religious ceremonies of more or less sedentary populations. Animals also became part of the household as pets, "giving" (again following Shaler and also Francis Galton, 1865) "aesthetic satisfaction" to humans. Herd animals, too, Sauer argued, would have first been brought into gentle captivity and reared like children. Only subsequently would breeding experimentations have occurred. Nor were today's chickens initially domesticated for functional (egg-laying and meat-producing) qualities, Sauer argued. Such characteristics were selected for later, at least in Malaysia and India, where originally animals were domesticated for ritual re-enactments of divine combat (in cock-fighting) and as gifts to spirits. He thus theorized domestication as a "cultural advance achieved only where people of special inclination ... gave peculiar and sustained attention to the care and propagation of certain plants and animals" (Sauer, 1952/1969, vii).

Not that Sauer was an uncritical advocate of domestication. Despite seeing the process as an "innovation" associated with the rise of Man (as Culture) to ecological dominance, he recognized in his paper for the 1955 symposium that settlement and pastoralism were progressively causing deleterious attrition of vegetative cover and surface soils. It was time to "take stock" - Sauer wrote in words that not only connected back to Shaler but forward to today's environmental impact rhetoric - of the "responsibilities and hazards of our prospects as lords of creation" (Sauer, 1952, 104). In other words, Man had singularly decoupled himself from evolutionary pressures and had thus been set on a path to civilization. What was needed now was for him to heed the negative consequences for his environments (or in today's ecology-speak, to acknowledge the "environmental limits" to our role at evolution's centre-stage).

Sauer's views on the origins of domestication were elaborated by other geographers, most notably the Simoons in their 1968 book about the ceremonial uses of the ox in India (see also Simoons, 1974), and Erich Isaac who, in 1970, published Geography of Domestication (see also Donkin, 1989; Palmieri, 1972). Isaac was concerned to develop the linkage between the domestication of cattle and religious ideas. After outlining a wealth of evidence, he concluded that the "cultivation and domestication of plants and animals were the by-product or outcome of a religious world picture" (Isaac, 1970, 110). It was an argument whose trend was "to reverse the popular Marxist axiom that religion and science are superstructures. For in this case, 
technology (domestication) was a superstructure on . . . religious knowledge" (Isaac, 1970, 110). To this day, key human geography texts such as Rubenstein (1989) and Fellman et al. (1990) carry forward this idealist position on the origins of domestication.

Such theorizations have recently been the focus of challenge from a number of directions, some internal to the framework of cultural ecology, others opening up the possibility of alternative understandings of domestication. Regarding the first line of critique, Rodrigue (1992) refutes on empirical grounds the Sauerian theory of animal domestication. Using archaeological data dating from periods spanning the transition from Upper Palaeolithic to Neolithic times in near-eastern sites, she tests the theory that ritual sacrifice induced the earliest animal domestications. Her data support the reverse argument; that ritual sacrifice occurred in societies that already possessed domestic animals, as well as stored and traded food. Her findings led her to reject the emphasis of cultural geographers on "the causal power of the human mind" (Rodrigue, $1992,427)$ and to claim instead that it was "fragile, destabilizing human ecosystems" that impelled decisions to settle and to elevate long-domesticated stock into "spiritual herds" (Rodrigue, 1992, 428).

Criticism of philosophical idealism in Sauerian cultural geography came from another, quite different, source in recent years. Whereas Rodrigue criticized Sauer within the frame of a (narrow) reading of culture as "learning", others sought to challenge more radically Sauerian forms of explanation. This line of critique queried not so much Sauer's empirical findings as the mode of conceptualizing culture that underpinned the Berkeley tradition. It is a critique that facilitates more critical thinking about domestication, of the kind that appears in the second part of this article.

In an influential article published in 1980, James Duncan laid out lines of disagreement with the Sauerian model of culture and elaborated the grounds for a revised view [...] ([see] Jackson, 1989; Anderson and Gale, 1992). Here I wish to think briefly through the implications of Duncan's ideas specifically for Sauerian views of domestication.

Duncan challenged many of the premises of the Berkeley school's theory of culture, many of which can be found threaded through Sauer's work on domestication. Most clear is Sauer's attribution of causal power for the "advance" of domestication to culture itself, as if culture were an agent that functioned somehow independently of individuals. This, after all, was Sauer's objective in relation to theorizing the origins of agriculture and animal husbandry: to deflect ecological and economic theorizations in favor of those that emphasized the force of culture in imprinting the face of the earth. For Sauer, culture was an evolutionary attribute uniquely acquired by man, one whose diverse religious expressions it was his project to document. In so doing, he granted culture "superorganic" power, reifying it as an abstraction with its own logic, rather than making the "learning" surrounding domestication the subject of its own explanation. 
Such a criticism does not compromise the detailed investigations of Sauer and others into the diffusion of specific domesticates. Indeed it is surely possible to query the evolutionary perspective of Sauer, without discrediting the often sophisticated contributions of the Berkeley school to regional studies of environmental, social and population change. Moreover, Sauer's focus on the ceremonial bases of domestication prompted him to address different symbolic systems in different places. But, in being content to explain, or more precisely explain away, animal sacrifice and selective breeding within a pregiven evolutionary trajectory - one that bestowed Culture on Man -- Sauer lost the opportunity of contextualizing domestication within a wider politics of premises and practices surrounding human uniqueness.

In what follows, I depart from treatments of domestication, including those outside geography such as Budiansky's (1995) spirited Covenant of the Wild, that explain species alteration in terms of some naturalized category of domestication. On the contrary, I see animal domestication as a political activity historically interconnected with ideas of human uniqueness and dominion, savagery and civilization that become woven into the structuring of not only human-animal relations but also other social arrangements. This is the subject of the substance of this article, to which I now turn.

\section{Deconstructing Animal Domestication}

\section{The Rise of the Idea of Human Uniqueness: Transcending "the Wild"}

Although the term "domestication" did not enter the English language until the $1500 \mathrm{~s}$, the practice of selectively breeding animals is rooted in the remote past. The verb to "domesticate" appears to be a technical term (deriving from the French domestiquer) that in medieval times became attached to a concept that had been circulating for centuries prior. We know that in the classical era, from approximately $500 \mathrm{BC}$ to the Roman period AD 100-300, domesticated beasts were the reference point for a rift in thought between "nature" which was said to be tame (the nature in Cicero's words, which "we make") and nature which was "indomitable" (Cicero, 1894).

Significantly, the opposition of domesticable and indomitable nature was no neutral distinction for the ancients. From at least the time of Hesiod's Works and Days in the eighth century $\mathrm{BC}$, human history was conceived as a journey from the age when man lived in (what was said to be) a "state of nature" (Glacken, 1967, 132-33). As various life-forms began to be recast practically by humans as food, energy, warmth, sport, company and so on, a process ensued that came to be narrated as the "cultivation" of nature. And to cultivate nature was to draw it into a moral order where it became (what was said to be) "civilized". Improvements of nature through the techniques of domestication were taken by Cicero, for example, to reflect human art in the fulfillment of Design in nature (Glacken, 1956, 72). 
The practice of refining life-forms was valorized as a marker of "humanness". It was the practice that signified "culture" itself, a term which in its earliest European use meant to cultivate or tend something, usually crops and animals (Williams, 1983, 87). By extension, nature, which lay beyond the orbit of cultivation, came to signify a space of danger and distance with tameness as its converse (Cosgrove, 1995). Indeed the walled city or polis of the classical era, where wildness would be kept out and the ideal moral community established, represented a major effort to segregate definitively civility and wildness (Pagden, 1982, 18-19). Later on, biblical stories invoked still more negative notions of wilderness (Cronon, 1995).

It is possible to historicize these concepts of civility and wildness further within the material and symbolic transformations called agriculture. One social archaeologist, Ian Hodder (1990), locates the distinction between civility and wildness remotely, in the Neolithic era, when experimentation with breeding of animals (and plants) was underway. The erection of more stable homes, the delimitation of settlement and the treatment of the dead all came to separate more securely the domestic from "the wild". While recognizing that the full range of meanings within Neolithic symbolic systems is lost to us, Hodder argues that built form in many archaeological sites throughout Europe was organized around the dramatic templates of the "domus" (where life sources such as clay, plants and animals, as wild, were brought in and transformed) and the "agrios" (as danger and death) beyond.

Note that the distinctions of domus and agrios are under constant construction, experimentation and negotiation as humans remake life sources and they remake humans. By the late fifth and fourth millennia BC, Hodder claims, the productive activities of cooking, feasting and exchange were couched within an ideology of the domus where that which was "wild" was domesticated into arrangements of coexistence with humans. From this perspective, the alteration of the relationship between humanity and other life-forms during the Neolithic - called agri-culture - was far broader than a functional rise in the activities of herding and harvesting (Thomas, 1991, 13). It was a simultaneously practical and symbolic process.

By the time of Greek writing, as early as Hesiod's Works and Days, the capacity of humans to domesticate life-forms had become quite deeply inflected with normative ideas. Such ideas have had an extraordinary resilience and were alive in the writings about domestication reviewed earlier in the article. Not only had domestication come to be narrated as the process out of which culture was constituted but it was also, for many Greek scholars, the very basis for the claim of human uniqueness (Frankfort et al., 1951).

Recognizing there were dissenting views (not least Porphyry's On Abstinence from Animal Food in AD 268), we can characterize the ancients' narrative logic as follows: whereas man (see note 2) could control his instincts through thought, animals were by contrast locked in the tyranny of instinct, unable to "realize their potential" (cited in Pagden, 1982, 17-18; Aristotle, 1976; see also Sorabji, 1993). Evidence for this claim was the art of cultivation through which humans had apparently improved 
"nature" (that is, brought it closer to the interests of humanity) (Pagden, 1982, 43). Now, of course, the animal world provided a reference point for the process of human self-definition long before domestication c. 11,000 BC (see, e.g., Hodder, 1990; Linzey and Yamamoto, 1998). But cultivation was decisive for most Greeks because it was taken as representing the systematic application of reason on the part of humans to their condition. The art of selective breeding had enabled humans to realize the "telos" [the end of a goal-oriented process] inherent within them and to transcend the primal struggle for survival. Animals by contrast were consigned to remain forever lodged in that struggle. They were stuck, not only in their own nature but also in the space called nature that was somehow left over and behind after humans, or at least Man - as Thought, Culture (and later on, Progress) - had heroically detached himself.

One has a further sense of the triumph with which domestication was viewed, in the classical idea that Man, in harnessing life-forms to his service, was said to be overcoming the force of instinct within himself. In so doing, he too became "civilized". He became free, released from what the ancients called his "animal nature". This was the metaphorical site within humans occupied by what loosely came to be called "the beast within", signifying all the contradictory fears and desires which surround uninhibited behavior, including sex and violence (Midgley, 1978). In short, a language of difference became expressed by the ancients in terms of a temporal metaphor of civilized and wild, human and animal, culture and nature.

The history of European ideas of animality, of the otherness of the nonhuman, is increasingly attracting a body of scholarship. There is a growing interest in how, instead of acknowledging species-specific diversity, humans came to draw a sharp dividing line between human and nonhuman such that we have perceived ourselves as belonging to a totally different order (called culture), while all other beings and inanimate things are only nature (Noske, 1989). We know that the human/animal distinction congealed under the weight of Christian premises about human dominion and an institution dedicated to curbing the animal within (although also that popular wisdom often clung to the more ominous belief that the boundary was not so secure). We also know that ideas about the integrity of the human species grew considerably more uncertain in medieval times when ambiguous and fantastic entities of mermaids, centaurs and other figures of sexual transgression entered myth and fable (Davidson, 1991). During the 1500s, there were some outspoken critics of the idea of human distinctiveness and superior station. Erasmus, Thomas More and Montaigne were, for example, bitter critics of hunting, an activity that rendered humans "beasts themselves" in the words of Erasmus (cited in Cockburn, 1996, 19). Thomas (1983) also reminds us that official notions of human mastery of the animal world in England during the early modern period were sometimes undercut by the unofficial efforts of farmers to nurture animals. But by the late 1600s, such romantic impulses had again been engulfed in views that the hand of a wise Providence was guiding humans whose duty on earth was to improve the primeval aspect of the earth through animal husbandry and tillage (Glacken, 1956, 75). 
From that time, with the development of the scientific revolution, the human capacity for reason became further exalted, and humanity was again opposed to animality (Cockburn, 1996). Earlier invocations to man's divine status were cast off. And when the French philosopher Descartes overlaid the earlier dualism of reason/nature with the distinction of mind and body - one which privileged the former (as the embodiment of intellect) over the latter (the locus of instinct) - the conceptual ground was further cleared to segregate human from animal (Midgley, 1984). While both were believed to be capable of physical sensation, Descartes deduced that since animals lack reasoning capacity, their sensations were merely bodily (physical/mechanical), ones of which they can't be aware or conscious (Lloyd, 1984). The categorical opposition of human and animal was thus further entrenched and the complex patterns of species-specific diversity slipped virtually entirely from popular view (Birke, 1991).

So taken for granted has the divide of human and animal become in western societies that the processes embedded in its construction have been obscured. As part of a strategy of retrieval, therefore, I have been foregrounding how formative classical ideas about animal difference and human uniqueness were historically conjoined with notions of culture and nature, and more precisely, "cultivating the wild". The couplet of civility and wildness belongs not only to the history of ideas, however, but also to real practices - specifically the material activities of selective breeding that gave humans control over the reproduction and character of other life-forms. The metaphorical and technical faces of domestication thus hold up a mirror to tensions within the process of "human" self definition in European-derived societies.

\section{Nature, Savagery and Civilization: Colonialism Beyond "Raced” Identities}

The practice of domesticating animals had embedded within it a structure of ideas surrounding the control, elaboration and "improvement" of wildness (into service and products). This had profound implications for human relations with the animal world, but also for intrahuman relationships and geographies. Negotiating the wild became a metaphor and mechanism for the regulation of European-derived societies.

With the development of the Enlightenment, the capacity of humans to reason - to transcend "the beast within" - came to colonize deeply not only western conceptions of human identity but also moral claims to humanness. The rational faculty (versus, for example, emotion, sensation and other sensibilities shared by all sentient creatures) was taken to stand as the defining characteristic of Human. The premise of a universal "human" subject was powerful enough to over-ride the internal contradiction of its own gendered and racialized inflection, as many feminist and antiracist critics have already noted (e.g., Plumwood, 1993; Birke, 1995). Those who were European, white, male and adult set themselves up as the prototype of humanity, with animality as its opposite. 
This sleight of hand relegated the feminine (equated with the body/the irrational), racialized peoples and children. All such "other people" had ambiguous status. While they were irrefutably "human", as people beyond reason they were not wholly spared of "animal-like" qualities. This was perhaps particularly the case for racialized peoples.

Under regimes of slavery in ancient Greece and also the sixteenth-century Americas, such peoples had performed a niche in human society because they were "like animals" (Jacoby, 1994). But the conflation of womanhood with the body (and its "wild" energy) was also a powerful and enduring couplet, as was the idea that children's "wild" behavior should be subject to "training" and discipline (as for animals).

The sense of "human" transcendence hardened with the rise of formal bodies of scientific knowledge from the eighteenth century which afforded (to themselves) the promise of fitting "nature" into models of regularity (Jay, 1992; Rose, 1993). Linneaus'Systema Naturae (1735) was especially influential in conceptually ordering nature's apparent chaos. It laid out a system of classification for plants and animals that became widely adopted despite (or perhaps because of) its logical base in the Aristotelian scala naturae or "great chain of being". Thus Man sat at its summit, with "higher" and "lower" organisms in descending order to the base. In such ways, despite being mixed with many folk ideas, (see Miller and Reill, 1996), science came to stand as the glorious incarnation of Mind.

Not that science was removed from earthly concerns. On the contrary, in the tradition of Bacon of utilizing science for the "relief of man's estate", improvement was an ethic that meshed easily with those of the Enlightenment. Fortified by the confidence in human reason that scientific achievements brought, Britain's landed elite embraced the secular rhetoric of this-worldly "improvement" of the earth's products. Waste lands could be brought into cultivation (an idea that lives on today in, for example, Australian mining company assessments of "unimproved" land as "useless", see Gelder and Jacobs, 1995). But not only that. As the eighteenth century progressed, the concept of improvement grew elastic enough to legitimize the expansion not only of agriculture but also industry and, ultimately, the development of colonies overseas (Gascoigne, 1994).

By the mid-eighteenth century, then, the ideal of improvement - one that had long justified selection of animals (and plants) for cultivation - became an informing ethic of European states undergoing schemes of empire-building. The frontiers of the "new world" could be reclaimed, symbolically and practically, from their wildness. As "blocks of space" inscribed with uncultivated landscapes, colonies were perceived to be stranded in the flow of social time (see Agnew, 1996). Stuck, as such, they joined the woods, the jungle, the frontier - all those primeval undomesticated spaces on to which could be (dis)placed the tensions within "human" identity-making surrounding the civil and the wild. The "telos" within such spaces could be "realized", however, by being "brought in" to the fold of a domus (empire or commonwealth) where wildness 
had been familiarized. Plant and animal species could be transferred from abroad as part of the "improvement" mission. An arm of the improvement strategy called "acclimatization" was thus extended to the "new world" after the example set in 1852 when the Société Zoologique et Botanique d'Acclimatation was established in Paris (Banks et al., 1994; Osborne, 1994).

Equally, certain peoples could be transformed into putatively more human humans. Just as nondomesticated plants were "weeds" and nondomesticated animals were "wild", nonwestern indigenous peoples typically bore the title of "savage". They were the people who stood at the beginning of social time, "unevolved" through having themselves remained undomesticated. (The term "savage" originally applied only to plants, but in the seventeenth century it came to acquire a more general reference to primitive peoples, Pagden, 1992, 14.) In the case of Australia's indigenous peoples, for example, it was their insistent nomadism that struck white settlers most forcefully. Aboriginals didn't have homes. Their camps were "part of nature"; that is, they weren't first modeled in the Mind, and then built or realized (see Ingold, 1995). The savages didn't live in cities (where to recall the ancients, all civil beings lived). Their resource management strategies didn't qualify as "agriculture". They didn't wear clothes. They ate a lot of raw food. Their tools and arms did not qualify as "technology". Patently, they didn't know how to realize their own human potential. Apparently (despite their nomadism), they were not yet "free". As shocking counterpoints to culture conceived primarily in terms of cultivation, sedentism, city life and technology, they unlocked the tensions within European models of what it meant to be "human".

Yet, according to the putatively universal ideal of human development as a series of stages from savagery through domestication to freedom (as witness G. Klemm's 1843 General Cultural History of Mankind and the earlier discussion of Shaler), the wildness of such savages could potentially be overcome. Through spatial containment and moral education - such as could be provided on missions - they could themselves learn to be domesticated. Under conditions of tuition, protection, pastoral care and discipline, primitives could be liberated of their savagery. A language of difference thus became expressed in terms of a temporal metaphor of wild and domesticated that justified a host of "civilizing" measures (see Guha, 1989, 240-44) and which again suggests how the myth of wildness belongs as much to a history of real people, real power, real practices and real geographies as to a history of ideas.

Charting practices and ideologies of improvement in this way enables us to rethink colonial encounters in fresh ways. Long conceived through the lenses of cultural transfer (e.g., Meinig, 1962; Powell, 1976; Williams, 1974), race domination/subjugation (Fredrickson, 1981; Pawson, 1992; Thomas, 1994), and regimes of extractive capitalism (e.g., Greenberg, 1980; Wallerstein, 1976) colonial relations might themselves be narrated within the frame of the much older process of domestication. The civilizing mission was not only about ethnically based supremacy and capitalist extension under Imperialism and modernity. Ideas of race hierarchy and 
strategies of capitalist extraction were nested within a more extensive framework of ideas about "human" uniqueness and dominion, a key material basis of which, I am arguing, lay in domestication of the nonhuman world. This was a source of ideas about perfectibility under selection practices, ${ }^{4}$ of improvement towards the goal of cultivating the wild, of mitigating backwardness, of reigning in and "fixing" wildness to a settled point.

Of course it has long been noted by race relations scholars that colonized and other racialized peoples were treated "like animals", as beasts closer to nature or as children in need of tutoring (e.g., Jordan, 1968). And the connections between Darwinian notions of survival, selection and fitness in nature and nineteenth-century ideas about race conflict have been widely documented (e.g., Stepan, 1982). But such scholarship has typically been cast within the frame of a critique of societal racism, using the contemporary analogies that were drawn to relations in nature as the subjectmatter for their critically deconstructive efforts, rather than taking the further step of situating multiple oppressions of colonized "races", nonhuman animals, "wild" landscapes and savage spaces within the legacy of domesticatory projects.

What I am proposing, then, is that once we begin to problematize social (including human/animal) relations within a wider politics of nature's domestication, broader modalities of power to do with civilizing the wild are brought into view. This is no quest on my part to assimilate (and depoliticize) all the diverse racialized practices under diverse European colonialisms into some overarching continuity flowing from the Neolithic to the present! Nothing so transhistorical, linear, totalizing or impregnable in scope is proposed. Nor is this a search for ultimate origins; we know, after Foucault, that history is partly constituted in the present, in the interpretation of the past. Indeed that is what I am suggesting: that the conceptual frame within which colonial relations in western societies are figured can be remembered differently and productively through being enlarged. By turning a spotlight on geographies of the "wild" - its management and all the disruptions that cross cut its containment - we might go some way to dislodging the petrified scripting of raced identities within the domination/resistance plot of contemporary anti- (and some post-) colonialist critiques.

${ }^{4}$ Notably, the science and practical program of eugenics, which was popular in Germany, Russia, Japan, the USA and Australia from the 1920s, was designed to promote racial quality and purity through selective breeding of the human species (see Stepan, 1982, 111-12). (Although note also that, in an extraordinary inversion, while brutal practices towards racialized humans were executed by Nazi Germans, animals rights were liberally trumpeted by Hitler and other Nazis - see Arluke and Sax, 1995.) 


\section{Neutering the Wild: The Gendered Politics of Domestication}

The first animal domestication practices required species to be positioned within the fold of the human "domus". (As noted earlier, this can be defined as the space of human concern set in opposition to "the wild" and including, without being restricted to, the household - Hodder, 1990.) People brought animals to them, rather than follow them across landscapes. This entailed the bounding and interiorization of space in which to keep out, tend, manage and generally familiarize "wild" nature in human terms. In early Neolithic settlements, goats and sheep were led away from their mountain habitats and reproductively isolated from their wild counterparts. Those species selected by humans to become a separate breed were spatially confined and over time socialized into new conditions of life. As animals became drawn into human production systems and living arrangements, cultural notions of "settling", ownership, property and possession were elaborated.

Space was significant in domestication practices not only in connection with an infrastructure of enclosure practices. Significantly, domestication involved a transition on the part of humans from predation to protection of food sources. Cultivation entailed the "husbandry" of animals (and plants). Such creatures were "reared" in a familial sphere, where they became habituated to people and people to animals. Animals were brought closer to an idea of humanity, and humans closer to a "nature" that was all the time being made more amenable to them (Thomas, 1983, Chap. 3). The most affectionate of such adoptions surrounded the raising of pets as part of a family (Tuan, 1984), but rearing extended much more impersonally and (in time) coercively, to farm animals.

Note in this context how the locus of the "house" came to lie within the parameters of a more inclusively domesticated nature. The gender implications of this arrangement need to be specified for precise times and places, but in even the most general terms, their importance deserves to be registered. Hodder (1990) argues that early concepts of the "domus" contained within them premises of "culturing the wild". These twin ideas, he argues, entailed the "bringing in" of not only animals, plants, clay and death but also the energy of female reproduction. Embedded within the idea of the cultured domus, then, might have been a politics of regulating the force of reproduction which did itself entail the early symbolic and spatial identification of women with the "hearth".

The lineage of gendered ideas and practices surrounding the house is not my concern here. Certainly the history is complex; for example, we know that in precapitalist Europe, domestic space was not rigidly gendered. Men and women shared more or less equally in the administration and productivity of, for example, the household (Hayden, 1984). In time, however, during the expansion of industrialism and imperialism, roles became more segregated. "Nature" that was as yet open to cultivation, discovery and rational inquiry became encoded with calls to masculinity. By contrast, "nature" that summoned forth images of things that were (either ideally or practically) tamed - the body, the home, the garden - was progressively feminized 
(Davis, 1995). The European ideal of womanhood came to figure women as domesticated, as beings attached to the concerns of the domus.

By eighteenth century England, the notions of ideal womanhood and "the home" had become conjoined (Armstrong, 1987, 83). The cultural tendency was for womanhood to be identified (narrowly) with reproductive roles and services imparted by domestic education (Brenzel, 1980; Ryan, 1982). Of course such ideological strictures on women were never fully or wholly binding and women have struggled in many western societies and at various times to overturn their identification with home conceived as a space of privacy, stasis, tradition and connectedness (see, e.g., Johnson, 1996). Regardless, such strictures grew materially significant with the progressive devaluation of domesticated "natures" under modernity (Shammas, 1980).

The critical conflation in much eco-feminist literature of women and nature in a patriarchal world (e.g., Collard, 1989; Merchant, 1980; Mies, 1990; Rosser, 1991; Shiva, 1989) appears to overlook this more precise comparison between women and domesticated nature. To explain the oppression of women/nature/animals in terms of male-centered environmental practices obscures the location of gendered relations of power within a more crucial nexus of domesticated/nondomesticated "natures". Other feminisms, in the constructivist tradition of the 1980s, have also overlooked the significance of domestication practices for their own concerns. They have insisted on women's place within "culture" rather than "nature", fearing that to position women within nature risks carrying forward deterministic equations of women with the world of animal atavism (e.g., MacCormack and Strathern, 1980). Nature has tended to be cast in terms as the presocial site of essentialist ideas about women (e.g., women as nurturers, women as emotional). In short, nature has been conceived as the site of the Innate from which women seek political distance (Birke, 1995, Chap. 8).

Such an anti-essentialist position has been, and continues to be, practically useful in overturning gendered inequality. But conflating the Innate with the Animal has had unintended consequences such as the following: it overlooks lines of continuity between primates (Haraway, 1989); it denies animals a cultural life (see, e.g., Masson and McCarthy, 1996) as well as politically trivializing any identification of women with the biological. More crucially, for my purposes here, it masks connections between the historical experiences of women and certain - that is, domesticated - life-forms.

By contrast, this article seeks to draw social relations previously conceptualized as "outside" nature into the wider network of a politics of domestication. Thinking through the lens of discursive regimes [abstract social systems which specify who can speak and what they can speak about, in what circumstances] of wildness and civility highlights trends and tensions within gendered relations that may repay further attention than is possible here.

Ultimately the focus leads beyond to the subject of human sexuality and the idea, increasingly class-based from the eighteenth century, that human "sexual nature" 
did itself require "cultivating" through the medium of its own domestication (Bewell, 1996). In the ideal bourgeois world where desire would be restrained and conduct disciplined, women came to be characterized as "civilizing agents". Their "wildness" properly reigned in and channeled into reproduction, they would be socializers of men within the domestic sphere. This was the space that came to stand ideologically as the antidote to competitive relations in nature and the modern marketplace (Armstrong, 1987). The implications of such a depoliticized concept of home space continue to resound in the problem of, and silence surrounding, domestic violence today.

\section{Domestication as Mastery?}

Talk of ideas of human transcendence of "nature" invokes [...] images of mastery and domination. In its technical meaning, domestication is a process of hereditary reorganization of animals into new forms according to human interests. It is a form of control whose subjects have undergone profound behavioral, as well as genetic and morphological, changes. (For example, the wild ancestors of cattle produced no more than a few liters of milk; the "best" cow can now yield 12,00010,000 liters during its lactation period.) Conceived metaphorically as the drawing of wildness into a fold where it could be "improved" and "settled", domestication also entailed some massively intrusive interventions in the circumstances of other lifeforms. In so far as the metaphor applies to the "dominions" of New South Wales, Victoria and South Australia, for example, many indigenous peoples in the nineteenth century were herded on to missions where their behavioral (and indeed reproductive) futures were strictly regulated.

Yet the constitutive processes of domestication are complex on closer inspection. Domestication practices brought humans and animals into sociospatial relations of not only control but also affinity, proximity as well as distance, companionship as well as service. Converting wolves into "dogs", tuberous perennials into "crops", aurochs into ever-more specialized "cows", has not always or only been a tyrannical act of domination over a haplessly subject nature. The underpinning moralities in domesticatory relations have been considerably more complex and contradictory, as I now seek to outline.

For all the calculation involved in the technical process of domestication, it is important to note that it has always been an experimental process. Neither traditional nor contemporary biotechnology is a confident imposition of mechanistic Order and Pattern, but rather involves tentative gestures of fear and hope. It is a process without guarantees of success or completion, and is subject to continuous refinement, reversal and failure.

Some species, such as gazelles, fled from efforts to confine them. Horses can become "brumbies", cats can go feral, the Australian dingo crossbreeds with domestic dogs and becomes more or less "wild". Even the staple domesticates on which humans 
have come to depend, including sheep, cows and chickens, cannot be considered definitively domesticated. Domestication is no completed accomplishment therefore; the actions of humans alone maintain tameness (Digard, 1992; Davis, 1995).

Animal domestication has also been an experimental process in the sense that it has drawn on a mix of moralities; of care and control, as well as mastery and paternalism. Depending on how a species is defined - whether it is deemed edible, palatable, useful, good company, vermin, nice to touch, intelligent and so on domestication has entailed impulses that range from consummate affection towards individual domesticates to unrestrained exploitation of whole species. The increasingly intensive conversion of animal productive capability into the bodily substances of meat, milk and wool (Benton and Redfearn, 1996; Ufkes, 1995) is the supremely coercive face of domestication. To domesticate in this form is indeed to appropriate. But contradictions run deep in the process, signaling cracks in its operation. Just as some people have always reserved their deepest commitments for their pets (Pitcher, 1996) and their most ardent affection for their gardens, one notes by today the return to small-scale organic farming in opposition to mass-produced systems of factory farming. In this move, an ethics of care resurfaces alongside - and often in conflict with - technocratic regimes of genetic engineering and sophisticated reproductive technologies (Bloomfield and Vurdubakis, 1995).

That domestication is no simple imposition of mastery is even more evident when threaded into the understanding of relations between groups of people. Certainly evidence of conflict and contest abounds in colonial and gendered relations, and need not be reiterated here. The couplet of wildness and civility that I have been foregrounding in this article, however, sheds further light on the nature of the struggles out of which such relations have been structured. For example, the disorder injected in the American governments' boarding-school regimes in the 1920s by teenage Indian girls - who adapted the tools of "domesticity classes" to their own ends (Lomawaima, 1993 ) - reminds us of the incomplete hold of models of domesticated womanhood on their often defiant subjects. Lines between wild and civilized are never, that is, definitively secure, and can always be transgressed, disturbed and recombined in unpredictable forms. ${ }^{5}$ As Rousseau (1754) signaled in his radical critique of humans' self-imposed domestication, people in apparently "civilized" societies can always take flight from the yearnings and fetters that fix them to settled home sites.

\footnotetext{
${ }^{5}$ See Jacobs (1996b) for signposts to new 'geophilosophies' of flight and flow.
} 
The diverse faces of domestication complicate simple conceptualizations of the process in the language of power and domination. The mix of control and care moralities also confounds the envisioning of alternative human-animal ethics that might flow from domestication's deconstruction. After all, the voices of "care" are not necessarily innately good (Plumwood, 1993, 188). Critical reflection on the process of domestication does, however, invite a less fearful recognition of "wildness" in the animal, the environment and the human Self. In a storyline that might flow from this recognition, wildness becomes scripted in terms of continuity and conversation, rather than opposition and othering [defining and securing one's own positive identity by stigmatizing others]. In such an "alter-tale" (Bennett, 1993, 251, after Haraway, 1991), knowing our place in the animal world (Baier, 1983) means relinquishing positions of control on the one hand, and the high ground of a global voice of "care" on the other, to acknowledge wildness without fear and sentimentality; to grant, in other words, "wildness" its ordinariness.

\section{Aestheticizing the Wild in City and Home}

As wildness became a residue within modernity from the end of the seventeenth century, human emotions that had been suppressed by the modern sensibility began to resurface. By the mid-eighteenth century in Europe, with the rise of aesthetics and varieties of romanticism, wild primeval nature was regularly "brought in" to spheres of human concern in stylized forms. Wildness itself became a source of nostalgia and affection, contemplation and inspiration (Cronon, 1995). Undomesticated difference became aestheticized. The wild became (in some contexts) sacred and exotic. Savages could as it suited be "noble". This notion of indigenous peoples transpired from at least the mid-eighteenth century when primitivism became cloaked to the romantic movement and woven into western constructs (see Jacobs, 1996a; Thomas, 1994).

As a cult of natural history spread through Western Europe and America (Jardine et al., 1996), so did popular efforts at creating varieties of animal (and plant) species. Amateur scientism became satisfied not only through experimentation with the breeding of old domesticates such as horses, cattle, sheep, pigs, dogs and cats (see Ritvo, 1991) but also through the selection of pigeons (Secord, 1981), aquarium fishes and plants for gardens. New varieties of "wildness" were not only brought into human living arrangements, but increasingly commercialized. In the nineteenth century, as industrialism and urbanization continued apace in western societies, the stylized wild was imported into home and city (Ritvo, 1992). Zoos and aquariums paraded "wild" animals for human audiences. Circuses transmuted fear into thrill. Models of subdued wildness also entered the home in safe (dead) form as fluffy toys for children and the likes of Constable's paintings of model gardens and cultivated countryside (Daniels, 1992). From the 1820s, in England, there was also a fad of collecting and pressing undomesticated natures, such as dead butterflies, beetles, spiders and the like into kaleidoscopic picture cases (Barber, 1984). Interestingly, these activities involved many women who - typically cast as part of domesticated nature - became natural 
history artists, collectors and patrons (see, e.g., Shteir, 1995; Society for the History of Natural History, 1996).

By today, city and home are replete with more or less commodified forms of wild, vanishing nature. Witness, for example, the lobbies of upmarket hotels where privatized space is symbolically rendered "public" by the interiorization of forest displays (see Gitlin, 1979); shopping malls, in which the high street is effectively domesticated; the growth of safari parks and various other sanitized eco-creations of the tourist trade that "bring in" and remake the wild. Witness, too, the uneasy and fragile displacement of fears surrounding racialized difference into aestheticized forms, as described by bell hooks (1992) in her essay "Eating the other".

The wilderness premise continues to carry forward the seductive notion implicit in much contemporary environmentalism - that nature, to be natural, must be untainted by humans (Cronon, 1995). Not only are spurious oppositions of culture and nature carried forward by such rhetorics, but some parts of "nature" are privileged at the expense of others. Mountains, tigers and polar expanses - undomesticated natures - rate considerably higher in popular back-to-nature treks than do socially selected creatures like chickens and budgies. Not only that, but to be concerned about the welfare of chickens or lambs is to be concerned about the most trivial of domesticated (feminized) nature. By contrast, wild animals and mountainous terrain, as yet unconquerable, hold out a call to a still masculinized higher status (Emel, 1995). This gendered distinction of domesticated and undomesticated natures further underlines the enduring cultural foundation of nature's production and arrangement.

\section{Conclusion: Feral Futures?}

At a time when elaborate reproductive technologies have come to deliver us not only animals and plants whose features are chosen by humans - but also the skills to engineer our very own species, it seems timely to take more rigorous stock of the record of selection practices by humans. And yet to date, while domestication has received extensive treatment in the academic literature of the natural and social sciences, its history has largely escaped critical attention. Given the enormous environmental, commercial and social impacts of the process - arguably as material as the much more extensively critiqued social formations of capitalism, patriarchy and racism with which domestication processes interacted - this silence is indeed surprising.

In this article I have sought to begin the task of deconstructing the process by which humans reshaped the disposition and biology of animals. Contrary to evolutionist schools which see animal domestication as a corollary of the rise of Man to ecological dominance, I have conceptualized domestication as a social-symbolic process. More precisely, I have problematized it within the narrative politics of ideas about human uniqueness, savagery and civilization through which the process was 
conceived and practiced from at least classical times. I have also charted how the ideological and material edifice of animal domestication became threaded through the construction of other social relations in European-derived societies. I noted that women often became defined and constructed as parts of an already domesticated nature, a coupling that historically limited the identification of women with the concerns of home, fertility and biological/social reproduction. So too have racialized groups been seen as closer to animals, an assignment that under regimes of slavery and colonialism rendered them and their "wild" lands eligible for "improvement" projects that owed a debt, I argued, to domestication practices. The notion of training and disciplining children may also have taken some of its moral direction from ideas of civilizing the wild.

Contemporary theorizations of difference are increasingly careful to note the complexity of social relations out of which class, ethnic, racially coded, sexualized and gendered identities have been constructed. The trend is to break with modernist theorizations of power in order to chart the disorganized faces of oppression, its unruly faces and its disruptions by minoritized groups. To domesticate the wild is to draw it into the boundaries of the known, to "fix" it into a (it is hoped) secure state. Yet as I have argued with reference to societies with a European cultural tradition, this is no transhistorical process of evolution's unfolding, but a political activity embedded within concrete human practices. It has diverse underpinning moralities, contradictory manifest forms, and is open to rupture and reversal. I here offer these thoughts as contributions to the envisioning of more complex and animal-inclusive models of social relations; interventions in the more intensive forms of animal agriculture; the relaxation of rigid oppositions of civility and wildness; and ultimately, a human Self more conversant with its own wild side, dedomesticated and unbound.

\section{References}

Agnew, J. 1996. Time into space: The myth of "backward" Italy in modern Europe. Time and Society 5, 27-45.

Anderson, K. and Gale, F. (eds.). 1992. Inventing Places: Studies in Cultural Geography. Melbourne: Longman.

Anderson, K. 1998. Science and the Savage: The Linnean Society of New South Wales, 1874-1900. Ecumene: International Journal of Culture, Environment and Meaning 5(2), 125-43.

Anderson, K. 1995. Culture and nature at the Adelaide Zoo: At the frontiers of "human" geography. Transactions, Institute of British Geographers NS 20, 2754. 
Aristotle 1976. How humans differ from other creatures. In T. Regan \& P. Singer (eds.), Animal Rights and Human Obligations. Englewood Cliffs, NJ: Prentice Hall.

Arluke, A. and B. Sax 1995. The Nazi treatment of animals and people. In, L. Birke \& R. Hubbard (eds.), Reinventing Biology. Bloomington, IN: Indiana University Press.

Arluke, A. and C. Sanders 1996. Regarding Animals: Animals, Culture and Society. Philadelphia, PA: Temple University Press.

Armstrong, N. 1987. Desire and Domestic Fiction: A Political History of the Novel. Oxford: Oxford University Press.

Baier, A. 1983. Knowing our place in the animal world. In, H. Miller \& W. Williams (eds.), Ethics and Animals. Clifton, NJ: Humana Press.

Baldwin, J. 1975. Notes and speculations on the domestication of the cat in Egypt. Anthropos 70, 428-48.

Banks, R., B. Elliott, J. Hawkes, King-Hele and G. Lucas (eds.). 1994. Sir Joseph Banks: A Global Perspective. London: The Royal Botanic Gardens, Kew.

Barber, L. 1984. The Heyday of Natural History, 1820-1870. London: Jonathan Cape.

bell hooks 1992. Black Looks: Race and Representation. Boston, MA: South End Press.

Bennett, J. 1993. Primate visions and alter-tales. In, J. Bennett \& W. Chaloupka (eds.), In the Nature of Things: Language, Politics and the Environment. Minneapolis, MN: University of Minnesota Press.

Benton, T. and S. Redfearn. 1996. The politics of animal rights - where is the left? New Left Review 215, 43-58.

Bewell, A. 1996. "On the banks of the South Sea": Botany and sexual controversy in the late eighteenth century. In, D. P. Miller \& P. H. Reill (eds.), Visions of Empire: Voyages, Botany and Representations of Nature. Cambridge: Cambridge University Press.

Birke, L. 1995. Feminism, Animals and Science: The Naming of the Shrew. Buckingham: Open University Press.

Birke, L. 1991. Science, feminism and animal natures. 1. Extending the boundaries. Women's Studies International Forum 14, 443-50. 
Bloomfield, B. and T. Vurdubakis. 1995. Disrupted boundaries: New productive technologies and the language of anxiety and expectation. Social Studies of Science 25, 533-51.

Brenzel, B. 1980. Domestication as reform: A study of the socialization of wayward girls, 1856-1905. Harvard Educational Review 50, 196-213.

Budiansky, S. 1995. The Covenant of the Wild: Why Animals Chose Domestication. London: Weidenfeld \& Nicolson.

Busch, L. 1991. Manufactured plants: Notes on the culture of nature and the nature of culture. International Journal of Agriculture and Food 1, 105-15.

Cicero. 1894. Tusculan Disputations: Also Treatises on the Nature of the Gods and on the Commonwealth. Trans. C. Yonge. New York: Harper \& Bros.

Clutton-Brock, J. (ed). 1989. The Walking Larder: Patterns of Domestication, Pastoralism, and predation. London: Unwin Hyman.

Clutton-Brock, J. 1981. Domesticated Animals from Early Times. Austin, TX: University of Texas Press.

Cockburn, C. 1996. A short, meat-oriented history of the world from Eden to the Mattole. New Left Review 215, 16-42.

Collard, A. 1989. Rape of the Wild: Man's Violence against Animals and the Earth. Bloomington, IN: Indiana University Press.

Cosgrove, D., P. Jackson, and J. Duncan. 1993. Commentary. Annals of the Association of American Geographers 83, 515-22.

Cosgrove, D. 1995. Habitable earth: Wilderness, empire, and race in America. In, D. Rathenberg (ed.), Wild Ideas, Minnesota, MN: University of Minnesota Press.

Cronon, W. 1995. Ideas of the wild. In, W. Cronon (ed.), Uncommon Ground: Towards Reinventing Nature. New York: W.W. Norton.

Daniels, S. 1992. Love and death across an English garden: Constable's paintings of his family's flower and kitchen gardens. The Huntington Library Quarterly 55, 433-57.

Davidson, A. 1991. The horror of monsters. In J. Sheehan \& M. Sosna (eds.), The Boundaries of Humanity: Humans, Animals, Machines. Berkeley, CA: University of California Press. 
Davis, K. 1995. Thinking like a chicken: farm animals and the feminine connection. In, C. Adams \& J. Donovan (eds.), Animals and Women: Feminist Theoretical Explorations. Durham, NC, and London: Duke University Press.

Linzey, A. and D. Yamamoto (eds.). 1998. Animals on the Agenda: Questions about Animals for Theology and Ethics. Chicago: University of Illinois Press.

Digard, J. 1992. A little known aspect of the history of the Americas: The domestication of animals. Homme 32, 122-24; 253-70.

Donkin, R. 1989. The Muscovy Duck, Cairina moschata domestica: Origins, Disperal, and Associated Aspects of the Geography of Domestication. Rotterdam: A.A. Balkema.

Duncan, J. 1980. The superorganic in American cultural geography. Annals of the Association of American Geographers 70, 181-98.

Emel, J. 1995. Are you man enough, big enough and bad enough? Ecofeminism and wolf eradication in the USA. Environment and Planning D: Society and Space $13,707-34$.

Fellman, J., A. Getis, J. and Getis. 1990. Human Geography: Landscapes of Human Activities. Dubuque, IA: William C. Brown.

Fitzsimmons, M. 1989. The matter of nature. Antipode 21, 106-20.

Frankfort, H., Mrs H. Frankfort, J. Wilson, and T. Jacobsen. 1951. Before Philosophy: The Intellectual Adventure of Ancient Man. Harmondsworth: Penguin Books.

Fredrickson, G. 1981. White Supremacy. New York: Oxford University Press.

Galton, F. 1865. The first steps towards the domestication of animals. Transactions of the Ethnological Society of London NS 3, 122-38 (reprinted in Inquiries into human faculty, London: Dent, 1907).

Gascoigne, J. 1994. Joseph Banks and the English Enlightenment: Useful Knowledge and Polite Culture. Cambridge: Cambridge University Press.

Gelder, K. and J. M. Jacobs. 1995. Uncanny Australia. Ecumene 2, 171-84.

Gitlin, T. 1979. Domesticating nature. Theory and Society 8, 291-97.

Glacken, C. 1967. Traces on the Rhodian Shore. Berkeley, CA: University of California Press. 
Glacken, C. 1956. Changing ideas of the habitable world. In, W.L. Thomas (ed.), Man's Role in Changing the Face of the Earth. Chicago, IL: University of Chicago Press.

Greenberg, S. 1980. Race and State in Capitalist Development: Comparative Perspectives. New Haven, CT: Yale University Press.

Guha, R. 1989. Dominance without hegemony and its historiography. In, R. Guha (ed.), Subaltern Studies. VI. Writings on South Asian History and Society. Delhi and Oxford: Oxford University Press.

Haraway, D. 1991. Simians, Cyborgs, and Women: The Reinvention of Nature. London: Free Association Books.

Haraway, D. 1989. Primate Visions: Gender, Race and Nature in the World of Modern science. New York and London: Routledge.

Harris, D. 1996. Domesticatory relationships of people, plants and animals. In, R. Ellen, \& F. Katsuyoshi (eds.), Redefining Nature: Ecology, Culture and Domestication. Oxford and Washington, DC: Berg.

Hayden, D. 1984. Redesigning the American Dream: The Future of Housing, Work, and Family Life. New York: Norton.

Hemmer, H. 1990. Domestication: The Decline of Environmental Appreciation. Trans. N. Beckhaus. Cambridge: Cambridge University Press.

Henry, D. 1989. From Foraging to Agriculture: The Levant at the End of the Ice Age. Philadelphia, PA: University of Pennsylvania Press.

Hodder, I. 1990. The Domestication of Europe: Structure and Contingency in Neolithic Societies. Oxford: Blackwell.

Ingold, T. 1992. Editorial. Man 27, 693-96.

Ingold, T. 1995. Building, dwelling, living: how animals and people make themselves at home in the world. In, M. Strathern (ed.), Shifting Contexts: Transformations in Anthropological Knowledge. London: Routledge.

Isaac, E. 1970. Geography of Domestication. Englewood Cliffs, NJ: Prentice Hall.

Jackson, P. 1989. Maps of Meaning. London: Unwin Hyman.

Jacobs, J. M. 1996a. Edge of Empire: Postcoloniality and the City. London: Routledge.

Jacobs, J. M. 1996b. Speaking always as geographers. Environment and Planning D: Society and Space 14, 379-83. 
Jacoby, K. 1994. Slaves by nature? Domestic animals and human slaves. Slavery and Abolition 15, 89-99.

Jardine, N., J. Secord and E. Spary (eds.). 1996. Cultures of Natural History. Cambridge: Cambridge University Press.

Jay, M. 1992. Scopic regimes of modernity. In Lash, S. \& Friedman, J. (eds.), Modernity and Identity. Oxford: Blackwell.

Johnson, L. 1996. "As housewives we are worms": Women, modernity and the home question. Cultural Studies 10, 449-63.

Jordan, W. 1968. White over Black: American Attitudes towards the Negro, 15501812. Baltimore, MD: Penguin Books.

Latour, B. 1993. We Have never Been Modern. London: Harvester-Wheatsheaf.

Livingstone, D. 1984. Science and society: Nathaniel S. Shaler and racial ideology. Transactions, Institute of British Geographers NS 9, 181-210.

Lloyd, G. 1984. The Man of Reason. London: Methuen.

Lomawaima, K. 1993. Domesticity in the federal Indian schools. American Ethnologist 20, 227-40.

MacCormack, C. and M. Strathern (eds.). 1980. Nature, Culture and Gender. Cambridge: Cambridge University Press.

Masson, J. and S. McCarthy. 1996. When Elephants Weep: The Emotional Lives of Animals. New York: Random House.

Meinig, D. 1962. On the Margins of the Good Earth. Washington, DC: Association of American Geographers.

Merchant, C. 1980. The Death of Nature: Women, Ecology and the Scientific Revolution. San Francisco, CA: Harper \& Row.

Midgley, M. 1984. Animals and Why They Matter. Athens, GA: Georgia University Press.

Midgley, M. 1978. Beast and Man: The Roots of Human Nature. Brighton: Harvester Press.

Mies, M. 1990. Women's studies: science, violence and responsibility. Women's Studies International Forum 13, 433-41. 
Miller, D. and Reill, P. (eds.). 1996. Visions of Empire: Voyages, Botany, and Respresentations of Nature. Cambridge: Cambridge University Press.

Noske, B. 1989. Humans and Other Animals: Beyond the Boundaries of Anthropology. London: Pluto Press.

Osborne, M. 1994. Nature, the Exotic and the Science of French Colonialism. Bloomington, IN: Indiana University Press.

Pagden, A. 1992: European encounters with the new world: from renaissance to romanticism. New Haven, CT, and London: Yale University Press.

Pagden, A. 1982. The Fall of Natural Man: The American Indian and the Origins of Comparative Ethnology. Cambridge: Cambridge University Press.

Palmieri, R. 1972. The domestication, exploitation and social functions of the yak in Tibet and adjoining areas. Proceedings of the Association of American Geographers 4, 80-3.

Pawson, E. 1992. Two New Zealands: Maori and European. In, K. Anderson \& F. Gale (eds.), Inventing Places: Studies in Cultural Geography. Melbourne: Longman Cheshire.

Philo, C. 1995: Animals, geography and the city: Notes on inclusions and exclusions. Environment and Planning D: Society and Space 13, 655-81.

Pitcher, G. 1996. The Dogs Who Came to Stay. London: Weidenfeld \& Nicolson.

Plumwood, V. 1993. Feminism and the Mastery of Nature. London: Routledge.

Powell, J. 1976. Environmental Management in Australia, 1788-1914. Oxford: Oxford University Press.

Price, M. and M. Lewis. 1993. The reinvention of cultural geography. Annals of the Association of American Geographers 83, 1-17.

Regan, T. 1983. The Case for Animal Rights. London: Routledge.

Ritvo, H. 1991. The animal connection. In, J. Sheehan \& M. Sosna (eds.), The Boundaries of Humanity: Humans, Animals, Machines. Berkeley, CA: University of California Press.

Ritvo, H. 1992. At the edge of the garden: Nature and domestication in eighteenth and nineteenth century Britain. The Huntington Library Quarterly 55, 363-78. 
Rodrigue, C. 1992. Can religion account for early animal domestication? A critical assessment of the cultural geographic argument, based on near eastern archaeological data. Professional Geographer 44, 417-30.

Rose, G. 1993. Feminism and Geography: The Limits of Geographical Knowledge. Cambridge: Polity Press.

Rosser, S. 1991. Ecofeminism: Lessons for feminism from ecology. Women's Studies International Forum 14, 143-52.

Rousseau, J.-J. 1754. Discourse on the Origins of Inequality. excerpts trans. in Chap. 5 of Mason, J. 1979. The Indispensable Rousseau. London: Quartet Books.

Rubenstein, J. 1989. The Cultural Landscape: An Introduction to Human Geography. Columbus, OH: Merrill Press.

Ryan, M. 1982. The empire of the mother: American writing about domesticity 18301860. Women and History 2-3, 1-170.

Sauer, C. 1952/1969. Seeds, Spades, Hearths, and Herds. 2nd ed. of Agricultural Origins and Dispersals. Cambridge, MA, and London: MIT Press.

Sauer, C. 1956. The agency of man on earth. In, W. Thomas (ed.), Man's Role in Changing the Face of the Earth. Chicago, IL: University of Chicago Press.

Secord, J. 1981. Nature's fancy: Charles Darwin and the breeding of pigeons. Isis 72, $163-86$.

Serpell, J. 1989. Pet-keeping and animal domestication: A reappraisal. In, J. CluttonBrock (ed.), The Walking Larder: Patterns of Domestication, Pastoralism, and Predation. London: Unwin Hyman.

Shaler, N. 1896. Domesticated Animals: Their Relation to Man and to His Advancement in Civilisation. London: Smith, Elder \& Co.

Shammas, C. 1980. The domestic environment in early modern England and America. Journal of Social History 14, 3-24.

Sheehan, J. and M. Sosna (eds.) 1991. The Boundaries of Humanity: Humans, Animals, Machines. Berkeley, CA: University of California Press.

Shiva, V. 1989. Staying Alive: Women, Ecology and Development. London: Zed Books.

Shteir, A. 1995. Cultivating Women, Cultivating Science: Flora's Daughters and Botany in England, 1760-1860. Baltimore, MD: Johns Hopkins University Press. 
Simoons, F. and Simoons, E. 1968. A Ceremonial Ox of India. Madison, WI, Milwaukee, WI, and London: University of Wisconsin Press.

Simoons, F. 1974. Contemporary research themes in the cultural geography of domesticated animals. Geographical Review 64, 557-76.

Singer, P. 1975. Animal Liberation. London: Jonathan Cape.

Smith, B. 1995. The Emergence of Agriculture. New York: Scientific American Library.

Smith, N. 1984. Uneven Development: Nature, Capital and the Production of Space. Oxford: Blackwell.

Snowden, F. 1983. Before Color Prejudice: The Ancient View of Blacks. Cambridge, MA: Harvard University Press.

Society for the History of Natural History (in association with Bodleian Library, Oxford) 1996. Women and Natural History: Artists, Collectors, Patrons, Scientists. Oxford: Bodleian and Parchment Printers.

Sorabji, R. 1993. Animal Minds and Human Morals: The Origins of the Western Debate. New York: Cornell University Press.

Stepan, N. 1982. The Idea of Race in Science: Great Britain, 1800-1960. London: Macmillan.

Thomas, J. 1991. Rethinking the Neolithic. Cambridge: Cambridge University Press.

Thomas, K. 1983. Man and the Natural World: Changing Attitudes in England, 15001800. London: Allen Lane.

Thomas, N. 1994. Colonialism's Cultures: Anthropology, Travel and Government. Melbourne: Melbourne University Press.

Thomas, W. L. (ed.). 1956. Man's Role in Changing the Face of the Earth. Chicago, IL: University of Chicago Press.

Tuan, Y.-F. 1984. Dominance and Affection: The Making of Pets. New Haven, CT: Yale University Press.

Ucko, P. and G. Dimbleby (eds.). 1969. The Domestication and Exploitation of Plants and Animals. London: Duckworth.

Ufkes, F. 1995. Lean and mean: US meatpacking in an era of agroindustrial restructuring. Environment and Planning D: Society and Space 13, 683-705. 
Wallerstein, I. 1976. The Modern World System. New York: Academic Press.

Williams, M. 1974. The Making of the South Australian Landscape: A Study in the Historical Geography of Australia. London and New York: Academic Press.

Williams, R. 1983. Key Words. London: Fontana.

Wilson, E. O. 1979. On Human Nature. New York: Bantam Books.

Wilson, P. 1988. The Domestication of the Human Species. New Haven, CT: Yale University Press.

Wolch, J. and J. Emel (eds.). 1997. Animal Geographies: Place, Politics and Identity in the Nature-Culture Borderlands. London: Verso.

Wolch, J., K. West, and T. Gaines. 1995. Transspecies urban theory. Environment and Planning D: Society and Space 13, 735-60.

Zeuner, F. 1963. A History of Domesticated Animals. London: Hutchinson. 